\title{
Penahanan Terhadap Anak Pelaku Tindak Pidana
}

\author{
Ardiko G.M. Sitompul, Haryadi, Tri Imam Munandar
}

Fakultas Hukum, Universitas Jambi

Author's Email Correspondence: ardikositompul95@gmail.com

\begin{abstract}
ABSTRAK
Penelitian ini bertujuan untuk memahami dan mengetahui faktor penahanan terhadap anak yang melakukan tindak pidana yang diancam pidana di bawah 7 (tujuh) tahun di Polres Tanjung Jabung Timur. Untuk memahami dan mengetahui kendala apa saja yang dihadapi dalam penahanan terhadap anak yang melakukan tindak pidana di bawah ancaman 7 (tujuh) tahun oleh Unit PPA Polres Tanjung Jabung Timur. Hasil Penelitian yang diperoleh dalam penelitian ini bahwa faktor yang menyebabkan penahanan terhadap pelaku anak yang dilakukan oleh Unit PPA Polres Tanjung Jabung adalah memberikan perlindungan terhadap ancaman serangan balasan dari korban, menghindari penghilangan barang bukti serta takut akan melarikan diri. Adapun kendala kendala yang dihadapi adalah terbatasnya sarana dan prasarana di Kabupaten Tanjung Jabung Timur sehingga tempat penahanan anak dilakukan di suatu ruangan khusus di Polres Tanjung Jabung Timur. Kurangnya dukungan dan kerjasama lembaga serta pelaksanaan ganti rugi yang tidak terlaksana sesuai kesepakatan.
\end{abstract}

\section{ARTICLE HISTORY}

Submission: 2020-11-22

Accepted: 2020-12-02

Publish: 2020-12-02

KEYWORDS: Child; criminal act; detention; offender.
Kata Kunci: Anak; pelaku; penahanan; tindak pidana.

ABSTRACT
This study aims to understand and determine the factors of
detention of children who commit criminal acts which are
punishable by under 7 (seven) years at the Tanjung Jabung
Timur Police. To understand and find out what obstacles are
faced in detention of children who commit criminal acts
under the threat of 7 (seven) years by the PPA Unit of the
Tanjung Jabung Timur Police. The results obtained in this
study indicate that the factors that led to the detention of
child perpetrators by the PPA Unit of the Tanjung Jabung
Police were providing protection against the threat of
retaliatory attacks from the victim, avoiding the loss of
evidence and fear of running away. The obstacles faced are
the limited facilities and infrastructure in East Tanjung
Jabung Regency so that the place for detention of children
is carried out in a special room at the Tanjung Jabung Timur
Police. Lack of institutional support and cooperation and
implementation of compensation that was not
implemented according to the agreement.

\section{A. PENDAHULUAN}

Anak merupakan bagian dari generasi muda yang memiliki peranan strategis yang mempunyai ciri dan sifat khusus, selain itu anak merupakan amanah dan karunia Tuhan Yang Maha Esa yang memiliki harkat dan martabat sebagai manusia seutuhnya (Undang-Undang Nomor 11 Tahun 2012 tentang peradilan pidana anak), oleh karena 
itu anak memerlukan perlindungan dalam rangka menjamin pertumbuhan dan perkembangan fisik, mental dan sosial secara utuh yang selaras dan seimbang.

"Anak sebagai generasi muda merupakan kekuatan sosial yang nantinya akan berperan sangat besar dalam pembangunan bangsa dan Negara, atas dasar inilah maka masyarakat dan pemerintah hendaknya menyadari perlunya suatu perhatian khusus yang diberikan terhadap anak, termasuk bila seandainya anak tersebut melakukan suatu perbuatan yang melanggar peraturan perundangundangan, dengan maksud agar anak tersebut jangan sampai mengalami tekenan jiwa dan jangan samapi proses perkara pidana yang mereka alami akan berpengaruh buruk bagi masa depan dan perkembangan jiwa anak". ${ }^{1}$

Pelaksaan perlindungan hukum bagi anak masih memerlukan perangkat peraturan perundang-undangan sebagai landasan yuridis bagi pelaksanaan kewajiban dan tanggung jawab keluarga, masyarakat, bangsa dan Negara. ${ }^{2}$

Indonesia merupakan salah satu dari 191 negara yang telah meratifikasi konvensi hak anak (Convention on the Right of Child) pada tahun 1990 melalui Kepres Nomor 36 Tahun 1990. Dengan meratifikasi konvensi ini, Indonesia memiliki kewajiban untuk memenuhi hak-hak bagi semua anak tanpa terkecuali. Salah satu hak anak yang perlu mendapat perhatian dan perlindungan adalah hak anak ketika berhadapan dengan hukum, khususnya ketika berada dalam penahanan.

Untuk mengembangkan tatanan dunia yang lebih baik terhadap anak, bukan pekerjaan yang sederhana, hak-hak anak sebagaimana digariskan dalam Konvensi Hak Anak, ditegakkan dalam situasi global dan realitas empiris yang paradox dengan prinsip kepentingan terbaik bagi anak dan hak-hak anak. ${ }^{3}$

"Dalam kenyataannya, banyak orang tua yang tidak menyadari hal ini, yang mempengaruhi perkembangan kehidupan anak. Anak yang dibesarkan dalam suasana konflik, cenderung mengalami keresahan jiwa, yang dapat mendorong anak melakukan tindakan-tindakan negatif, yang dikategorikan sebagai kenakalan anak. Anak melakukan kenakalan, dapat dipengaruhi oleh latar belakang kehidupannya. Kenakalan anak bukan hanya merupakan gangguan terhadap keamanan dan ketertiban masyarakat, tetapi juga mengancam masa depan bangsa dan Negara". ${ }^{4}$

Seorang anak dalam menjalani proses kehidupannya pasti akan melalui fase atau tahapan kehidupan. Adapun fase yang akan dilalui anak yaitu fase remaja atau adolescent, yang dimaksud dengan fase remaja adalah suatu proses transisi atau masamasa perpindahan dari fase anak-anak menuju fase dewasa, pada fase ini ditemukan bahwa anak akan menunjukan tingkah laku anti sosial, kemudian disertai banyak pergolakan hati dan jiwa, fase ini anak dapat membuat anak kehilangan kontrol atas emosinya, sehingga untuk menanggulangi hal tersebut dibutuhkan pembinaan dan pengawasan oleh segala pihak terutama pihak keluarga, karena jika tidak adanya

1 Hafrida, Perlindungan Hukum Terhadap Anak Pelaku Tindak Pidana Pada Proses Penyidikan, Jurnal Ilmu Hukum, Volume 5, Nomor 6, Januari 2012, hlm. 52. https://scholar.google.com/citations?user=xT8MpbIAAAAJ\&hl=en

2 Prakoso Abintoro, Hukum Perlindungan Anak, Laksbang Pressindo, Yogyakarta, 2016, hlm. 2.

Ibid, hlm. 59.

4 Gultom Maidin, Perlindungan Hukum Terhadap Anak, Cet. 4, Edisi. Revisi, Refika Aditama, Bandung. 2014, hlm. 2. 
pembinaan dan pengawasan maka dikhawatirkan akan menimbulkan suatu kenakalan yang pada akhirnya dapat mengarah kepada tindakan yang bersifat kriminalitas

"Pasal 2 Undang-Undang Sistem Peradilan Pidana Anak, menentukan bahwa sistem peradilan pidana anak, dilaksanakan berdasarkan asas: perlindungan; keadilan; nondiskriminasi; kepentingan terbaik untuk anak; penghargaan terhadap pendapat anak ; kelangsungan hidup dan tumbuh kembang anak; pembinaan dan pembimbingan anak; proporsional; perampasan kemerdekaan dan pembinaan sebagai upaya terakhir; dan penghindaran pembalasan. Dalam kenyataannya hal ini belum dilaksanakan sebagaimana mestinya". ${ }^{5}$

Hak perlindungan, hak kelangsungan hidup, hak untuk tumbuh dan berkembang dengan baik, merupakan hak fundamental anak. Hak fundamental tersebut merupakan nilai subtantif dalam kebijakan anak dan harus dilaksanakan secara konsisten dan berkesinambungan. ${ }^{6}$

Dalam menghadapi dan menanggulangi berbagai perbuatan dan tingkah anak nakal, perlu dipertimbangkan kedudukan anak dengan segala ciri dan sifat khasnya. Walaupun anak telah dapat menentukan sendiri langkah perbuatannya berdasarkan pikiran, perasaan dan kehendaknya, tetapi keadaan sekitar dapat mempengaruhi perilakunya. Oleh karena itu dalam menghadapi masalah anak nakal, orang tua dan masyarakat sekelilingnya seharusnya lebih bertanggung jawab terhadap pembinaan, pendidikan dan perkembangan perilaku anak tersebut.

"Tindakan kenakalan yang dilakukan oleh anak-anak merupakan manifestasi dari kepuberan remaja tanpa ada maksud merugikan orang lain seperti yang diisyaratkan dalam suatu perbuatan kejahatan yang tercantum dalam Kitab Undang-Undang Hukum Pidana (KUHP) di mana pelaku harus menyadari akibat dari perbuatannya itu serta pelaku mampu bertanggung jawab terhadap perbuatannya tersebut. Dengan demikian, maka, kurang pas apabila kenakalan anak dianggap sebuah kejahatan murni". ${ }^{7}$

Pada Pasal 32 ayat (1) dan (2) Undang-Undang Nomor 11 Tahun 2012 tentang Sistem Peradilan Pidana Anak menjelaskan bahwa penahanan terhadap anak untuk proses penyidikan dilakukan paling lama 7 (tujuh) hari, dan dapat diperpanjang selama 8 (delapan) hari. Anak yang ditangkap wajib ditempatkan dalam ruang pelayanan khusus anak, dan tidak boleh digabungkan atau disamakan dengan tempat orang dewasa ditahan.

Penahanan dalam bentuk apapun yang dilakukan, pada hakekatnya merupakan pembatasan gerak dan aktifitas dari orang yang ditahan. Dengan demikian penahanan juga merupakan suatu bentuk perampasan kemerdekaan, yaitu kemerdekaan bergerak dan beraktifitas. Dalam kondisi demikian ini, penahanan juga dapat menimbulkan dampak negatif, tidak hanya terdapat pada diri orang yang ditahan, tapi juga merekamereka yang dekat dan menjadi tanggung jawab orang yang ditahan (dalam hal pemenuhan kebutuhan hidup).

5 Gultom Maidin, Perlindungan Hukum Terhadap Anak, Cet. 4, Edisi. Revisi, Refika Aditama, Bandung. 2014, hlm. 40.

6 Sudarti Elly, Perlindungan Hak Anak Dalam Penyidikan, Jurnal Ilmu Hukum, Volume 15, Nomor 1, April 2007, hlm. 55. https://www.neliti.com/id/journals/jurnal-ilmu-hukumjambi

7 M. Nasir Djamil, Anak Bukan Untuk Dihukum, Cet. 3, Sinar Grafika, Jakarta, 2015, hlm. 34-35. 
Di Provinsi Jambi perkembangan anak bisa dibilang sangat cepat, baik dari tingkah laku, perbuatan maupun secara fisik, dimana pergaulan yang terjadi dikalangan anak begitu cepat dipengaruhi oleh arus globalisasi informasi, komunikasi dan gaya hidup sehingga tidak sedikit dari mereka terlena dan bahkan melakukan tindakan-tindakan pidana.

Di Provinsi Jambi terdiri dari; 1 (satu) Polda, dengan jajarannya meliputi; 1 (satu) Polresta dan 9 (Sembilan) Polres. Dari beberapa jajaran kesatuan tersebut, terdapat data anak yang ditahan yang ancaman hukuman penjaranya di bawah 7 (tujuh) tahun. Data tersebut di dapatkan dari tahun 2017 sampai dengan 2019.

Tabel 1

Data anak yang melakukan tindak pidana yang ancaman hukuman di bawah tujuh tahun dan ditahan

\begin{tabular}{cccccc}
\hline \multirow{2}{*}{ NO } & \multirow{2}{*}{ KESATUAN } & \multicolumn{3}{c}{ TAHUN } & \multirow{2}{*}{ TOTAL } \\
\cline { 3 - 5 } & & $\mathbf{2 0 1 7}$ & $\mathbf{2 0 1 8}$ & $\mathbf{2 0 1 9}$ & \\
\hline 1. & POLDA JAMBI & - & - & - & - \\
\hline 2. & POLRESTA JAMBI & - & - & 1 & 1 \\
\hline 3. & POLRES BATANGHARI & - & - & - & - \\
\hline 4. & POLRES MUARO JAMBI & - & 1 & - & 1 \\
\hline 5. & POLRES TANJUNG JABUNG BARAT & - & 4 & - & 4 \\
\hline 6. & POLRES TANJUNG JABUNG TIMUR & 1 & 2 & 1 & 4 \\
\hline 7. & POLRES BUNGO & - & 1 & - & 1 \\
\hline 8. & POLRES TEBO & - & 2 & 2 & 4 \\
\hline 9. & POLRES MERANGIN & - & 2 & 2 & 4 \\
\hline 10. & POLRES SAROLANGUN & - & - & 3 & 3 \\
\hline 11. & POLRES KERINCI & - & 3 & - & 3 \\
\hline \multicolumn{7}{r}{} & JUMLAH KESELURUHAN & & & 26 \\
\hline
\end{tabular}

Sumber: Direktorat Reserse Kriminal Umum, Polda Jambi

Berdasarkan dari data di atas, dari tahun 2017 sampai dengan 2019 kasus anak yang di tahan oleh pihak Kepolisian yang ancamannya hukumannya di bawah 7 (tujuh) tahun berjumlah 26 kasus di Provinsi Jambi 4 (empat) kasus di antaranya berada di Polres Tanjung Jabung Timur. Hal ini mendorong penulis untuk mengambil penelitian di Polres Tanjung Jabung Timur, dengan alasan mengambil penelitian di Polres Tanjung Jabung Timur yaitu:

1. Kabupaten Tanjung Jabung Timur merupakan salah satu kabupaten baru di provinsi Jambi yang merupakan pecahan dari Kabupaten Tanjung Jabung yang mana dulu ibukota Kabupaten berada di Kuala Tungkal yang sekarang menjadi Kabupaten Tanjung Jabung Barat.

2. Dari data jumlah penduduk di Kabupaten Tanjung Jabung Timur merupakan Kabupaten yang memiliki jumlah penduduk paling Rendah di tingkat Kabupaten seprovinsi Jambi, terhitung dari Tahun 2010 - 2018. 
3. Dari data kepadatan penduduk Kabupaten Tanjung Jabung Timur juga merupakan Kabupaten yang berada paling bawah dengan tingkat kepadatan yang paling rendah diantara Kabupaten lainnya di Provinsi Jambi.

4. Dari seluruh Kabupaten di Provinsi Jambi, Kabupaten Tanjung Jabung Timur salah satu jarak penelitiannya lebih dekat dan lebih memadai dari tempat tinggal, sehingga lebih mudah untuk melakukan penelitian di Kabupaten tersebut.

5. Kabupaten Tanjung Jabung Timur termasuk salah satu presentasi terbanyak anak melakukan tindak kejahatan, dari kabupaten lainnya.

Penelitian ini dilakukan guna mengetahui penahanan anak dan kendala yang dihadapi oleh pihak kepolisian dalam mengangani kasus anak sebagai pelaku. Penahanan terhadap anak sangat jauh berbeda dengan penahanan orang dewasa, penahanan orang dewasa di atur dalam Undang-Undang Nomor 08 Tahun 1981 Tentang Kitab Undang-Undang Hukum Pidana (KUHAP), sedangkan penahanan terhadap Anak di atur dalam Undang-Undang Nomor 11 Tahun 2012 Tentang Sistem Peradilan Pidana Anak.

Di Polres Tanjung Jabung Timur terdapat 4 (empat) kasus anak yang melakukan tindak pidana yang ancaman pidananya dibawah dibawah 7 (tujuh) tahun. Dari empat kasus tersebut, semua anak ditahan oleh pihak kepolisian. Padahal di dalam Pasal 32 ayat (2) Undang-Undang Nomor 11 Tahun 2012 Tentang Sistem Peradilan Pidana Anak jelas tertulis; bahwa penahanan terhadap anak hanya dapat dilakukan dengan syarat sebagai berikut:

a. Anak telah berumur 14 (empat belas) tahun atau lebih; dan

b. Diduga melakukan tindak pidana dengan ancaman pidana penjara 7 (tujuh) tahun atau lebih.

Menurut Pasal 32 ayat (1) Undang-undang Nomor 11 Tahun 2012 Tentang Sistem Peradilan Pidana Anak (SPPA) bahwa; penahanan terhadap anak tidak boleh dilakukan dalam hal anak memperoleh jaminan dari orang tua/wali dan/atau lembaga bahwa anak tidak akan melarikan diri, tidak akan menghilangkan atau merusak barang bukti, dan/atau tidak akan mengulangi tindak pidana.

Dari tabel di atas adalah jumlah kasus anak sebagai pelaku tindak pidana yang ditahan oleh pihak Kepolisian, dengan ancaman hukuman di bawah 7 (tujuh) tahun, dan pelaku tersebut bukanlah merupakan pengulangan tindak pidana.

"Penahanan anak (Detention pending trial), hendaklah merupakan suatu upaya terakhir karena akibat-akibat negatif dari penempatan anak dalam suatu lembaga tidak hanya karena hilangnya kemerdekaan itu sendiri tetapi juga karena dipisahkannya anak tersebut dari lingkungan sosialnya yang biasa. Kalaupun memang sangat baku untuk dilakukan penahanan maka harus digunakan sebagai tindakan terakhir dan dalam waktu sesingkat mungkin, dan selama berada dalam tahanan anak harus memperoleh semua hak dan jaminanjaminan menurut peraturan perundang-undangan yang berlaku". ${ }^{8}$

8 Hafrida, Perlindungan Hukum Terhadap Anak Pelaku Tindak Pidana Pada Proses Penyidikan, Jurnal Ilmu Hukum, Volume 5, Nomor 6, Januari 2012, hlm. 59. https://scholar.google.com/citations?user=xT8MpbIAAAAJ\&hl=en 
Jadi, jika tempat penahanan anak disamakan dengan tempat penahanan orang dewasa, hal tersebut bisa mengakibatkan anak menjadi stres, dapat merusak psikologi anak, dan dapat merusak mental anak tersubut.

"Anak haruslah ditangani secara berbeda dengan orang dewasa. Sebagaimana yang disampaikan sebelumnya, anak yang dipidana terlabel dan terstigmatisasi selepas pemidanaan sehingga menyulitkan pertumbukan psikis dan sosial anak ke depan. Ketiga, memulihkan hubungan antara anak yang berhadapan dengan hukum, korban, dan masyarakat". ${ }^{9}$

\section{B. METODE PENELITIAN}

Metode penelitian yang digunakan dalam penelitian ini adalah pendekatan yuridis empiris. Yuridis yaitu mengkaji konsep normatifnya atau peraturan perundangundangan, sedangkan empiris yaitu mengkaji pada kenyataan yang ada terhadap penahanan terhadap anak yang melakukan tindak pidana dengan ancaman hukuman di bawah tujuh tahun di Polres Tanjung Jabung Timur.

\section{PEMBAHASAN}

1. Faktor Yang Menyebabkan Pihak Kepolisian Menahan Pelaku Anak Yang Melakukan Tindak Pidana Dengan Ancaman Hukuman di Bawah 7 (tujuh) Tahun di Polres Tanjung Jabung Timur

Kepolisian merupakan salah satu fungsi pemerintahan Negara di bidang keamanan dan ketertiban masyarakat, penegakan Hukum, perlindungan, pengayoman dan pelayan kepada masyarakat.

Kepolisian Resort (POLRES) merupakan struktur komando kepolisian/ pelaksana tugas kepolisian Republik Indonesia di daerah Kabupaten/kota (kab. Tanjung Jabung Timur, Jambi). Salah satu tugas/wewenang dari kepolisian adalah melaksanakan tugas penyelidikan, penahanan, dan penyidikan dalam bidang peradilan. Adapun perkara pidana yang ditangani Kepolisian salah satunya yaitu perkara pidana yang pelakunya adalah anak.

Penyidik ialah pejabat polisi Negara Republik Indonesia atau pejabat pegawai negeri sipil tertentu yang diberikan wewenang khusus oleh Undang-Undang untuk melakukan penyidikan. Penyidik pada kasus anak disebut penyidik anak yang langsung bersentuhan dengan anak-anak yang berhadapan dengan hukum dalam menyelesaikan kasus, dalam menjalankan tugasnya pihak Kepolisian Tanjung Jabung Timur memiliki unit khusus menangani anak-anak. Unit Perlindungan Perempuan dan Anak (UPPA) yang merupakan salah satu unit khusus yang berada dalam struktur organisasi Reskrim Polres Tanjung Jabung Timur dimana UPPA memiliki fungsi dan tugas tersendiri, dimana kasus kejahatan yang ditangani oleh UPPA berkisar pada wanita dan anak-anak.

Berikut ini adalah data tentang perkara pidana anak yang di tangani oleh UPPA Kepolisian Resort (POLRES) Tanjung Jabung Timur.

\footnotetext{
9 Ibid, hlm., 4.
} 
Tabel 2

Data anak yang melakukan tindak pidana yang ancaman hukuman di bawah tujuh tahun dan ditahan Polres Tanjung Jabung Timur

\begin{tabular}{ccccc}
\hline No & Tahun & $\begin{array}{c}\text { Kasus Tindak } \\
\text { Pidana }\end{array}$ & $\begin{array}{c}\text { Jenis Tindak } \\
\text { Pidana }\end{array}$ & Total \\
\hline 1. & 2017 & 1 & 351 ayat $(2)$ & 1 \\
\hline 2. & 2018 & 2 & 170 ayat $(1)$ & 2 \\
\hline 3. & 2019 & 1 & 362 & 1 \\
\hline & \multicolumn{5}{c}{ Jumlah } & 4 \\
\hline
\end{tabular}

Sumber: Direktorat Reserse Kriminal Umum, Polda Jambi

Dilihat dari data tabel 2 di atas menjelaskan bahwa perkara pidana anak yang ditahan yang ancaman hukumannya di bawah 7 (tujuh) tahun berjumlah 4 (empat) dari tahun 2017 sampai dengan 2019, di tahun 2017 berjumlah 1 (satu) orang, tahun 2018 berjumlah 2 (dua) orang, dan di tahun 2019 berjumlah 1(satu) orang. Ini menjelaskan dari 3 (tiga) tahun terakhir perkara pidana yang ditangani oleh Polres Tanjung Jabung Timur meski jumlahnya Fluktuatif (berubah-ubah) tapi tak dapat dipungkiri tidak hanya orang dewasa yang melakukan tindak pidana melainkan juga anak-anak.

Pada ke 4 (empat) kasus di atas menjelaskan jumlah tindak pidana yang dilakukan oleh anak. Selama 3 (tiga) tahun terakhir dari tahun 2017 sampai dengan 2019 yang di tangani Polres Tanjung Jabung Timur, jumlah tindak pidana yang dilakukan oleh anak adalah tindak pidana penganiayaan dengan luka berat pada tahun 2017 dengan 1 (satu) kasus, tindak pidana pengeroyokan pada tahun 2018 dengan jumlah kasus 2 (dua) dan pencuri biasa di tahun 2019 dengan jumlah 1 (satu) kasus. Ke empat kasus ini semuanya anak di bawah 18 (delapan belas) tahun, dan bukan pengulangan tindak pidana.

Adapun ke 4 (empat) kasus di atas seluruhnya anak ditahan oleh pihak Kepolisian Tanjung Jabung Timur, walaupun ke 4 (empat) kasus di atas tersebut tindak pidana yang dilakukan ancaman pidana penjara di bawah 7 (tujuh) tahun dengan alasan; dikhawatirkan menghilangkan barang bukti, takut akan melarikan diri, dan melindungi pelaku dari serangan balasan dari pihak korban.

Berdasarkan hasil wawancara dengan AKP Gokma Uliate Sitompul selaku mantan Kasat Reskrim Polres Tanjung Jabung Timur, mengatakan bawah:

"Proses Penahanan dilakukan karena tindakan tersebut sangat diperlukan mengingat tentang keselamatan anak (menghindari pembalasan) tersebut, dan untuk kepentingan tugas/penyidikan ke depan, serta mempertimbangan ketertiban umum di tempat kejadian. Dalam hal ini, kami sebagai penyidik, walaupun ancaman hukuman tindak pidana yang dilakukan anak tersebut dibawah 7 (tujuh) tahun penahanan tetap dilakukan salah satunya atas dasar Diskresi Kepolisian sebagaimana tertuang dalam Undang-Undang Nomor 2 Tahun 2002 tentang Kepolisian Negara Republik Indonesia”.10

10 AKP Gokma Uliate Sitompul, selaku Kasat Reskrim Polres Tanjung Jabung Timur, Wawancara tanggal 15 Oktober 2019. 
Walaupun sudah jelas tertulis di Pasal 32 ayat 2 Undang-Undang Nomor 11 Tahun 2012 Tentang Sistem Peradilan Pidana Anak, bahwa Penahanan terhadap Anak hanya dapat dilakukan dengan 2 (dua) syarat yaitu:

a. Anak telah berumur 14 (empat belas) tahun atau lebih; dan

b. Diduga melakukan Tindak Pidana dengan ancaman pidana penjara 7 (tujuh) tahun atau lebih.

Padahal jika ingin melakukan penahanan, ke 2 (dua) syarat tersebut harus terpenuhi semua, tidak boleh hanya salah satunya saja. Dikarenakan di pasal 32 ayat 2 Undang-Undang Sistem Peradilan Pidana Anak memakai kata DAN bukan ATAU.

Ketika berbicara tentang penahanan, jangka waktu penahanan anak lebih singkat dari pada jangka waktu penahanan orang dewasa. Pada pasal 33 ayat (1),(2),(3) Undang-Undang Nomor 11 Tahun 2012 tentang Sistem Peradilan Pidana Anak menjelaskan bahwa jangka waktu penahanan untuk kepentingan penyidik, paling lama adalah 7 (tujuh) hari, untuk kepentingan pemeriksaan yang belum selesai, dapat diperpanjang paling lama 8 (delapan) hari. jika dalam hal jangka waktu yang telah diberikan belum juga selesai, maka anak wajib dikeluarkan demi hukum.

Selanjutnya hasil wawancara dengan Brigadir Riky. R. Siahaan selaku Kanit Perlindungan Perempuan dan Anak (PPA) di Polres Tanjung Jabung Timur, mengatakan bahwa ada 2 faktor dilakukan penahanan yaitu: ${ }^{11}$

1. Secara Formal

Dikarenakan ancamannya di bawah 7 (tujuh) tahun sebagaimana tertulis di Undang-Undang Nomor 11 Tahun 2012 penahanan tetap dilakukan karena di kawatirkan pelaku; melarikan diri, melakukan tindak pidana lagi, dan menghilangkan barang bukti.

2. Secara Non Formal

Bahwa seperti dikatakan oleh Bapak KASAT RESKRIM AKP Gokma Uliate Sitompul, S.H. bahwa dilakukannya penahanan semata-mata melindungi anak dari serangan balasan dari korban.

Diskresi hanya dapat dilakukan oleh pejabat pemerintahan yang berwenang, salah satunya ialah Kepolisian. Peranan Kepolisian dalam penegakan hukum dapat ditemukan didalam Undang-Undang Nomor 2 Tahun 2002 Tentang Kepolisian Negara Republik Indonesia.

Polisi, dalam suatu sistem peradilan pidana adalah awal dari proses tersebut. Di banyak Negara, polisi mempunyai suatu otoritas legal yang disebut sebagai diskresi. ${ }^{12}$

Penyidik anak dalam melaksanakan tugas dan fungsinya memiliki beberapa kewenangan dalam penyelidikan dan penyidikan dan itu kewenangan yang legal, salah satu kewenangannya ialah kewenangan Diskresi.

Berdasarkan hasil dari wawancara dari Brigadir Riky R. Siahaan selaku Kanit Unit PPA di Polres Tanjung Jabung Timur, mengatakan bahwa:

"Diskresi adalah suatu kebijaksanaan, keleluasaan untuk mengambil suatu keputusan berdasarkan keyakinan".13

11 Brigadir Riky. R. Siahaan, selaku Kanit Unit Perlindungan Perempuan dan Anak Polres Tanjung Jabung Timur, Wawancara tanggal 15 Oktober 2019.

12 Sudarti Elly, Perlindungan Hak Anak Dalam Penyidikan, Jurnal Ilmu Hukum, Volume 15, Nomor 1, April 2007, hlm. 56. https://www.neliti.com/id/journals/jurnal-ilmu-hukumjambi 
Dalam melaksanakan tugasnya, Penyidik ketika mempertimbangkan tindak pidana yang dilakukan oleh anak yaitu umur anak, hasil penelitian kemasyarakatan dari BAPAS, kerugian yang ditimbulkan atas perilaku anak tersebut, bagaimana tingkat perhatian dan pendapat masyarakat atas kasus tersebut, dan dukungan lingkungan keluarga dan masyarakat. Tidak semua kasus anak dapat dilakukan Penahanan karena pelaksanaan Penahanan harus terlebih dahulu mendapatkan kesepakatan keluarga.

Berdasarkan hasil wawancara dengan Aipda Juniar Simanjuntak selaku Kanit Unit PPA Tahun 2011-2019 di Polres Tanjung Jabung Timur, mengatakan bahwa:

"BAPAS dan Pembimbing Kemasyarakatan adalah unsur lembaga yang sangat berperan dalam proses pengawasan dan penyambung lidah Kepolisian tentang tindakan Kepolisian yang dilakukan kepada masyarakat khususnya pihak korban dan keluarga pelaku mengingat lembaga lain yang seharusnya turut serta belum ada di kabupaten Tanjung Jabung Timur". 14

Dari pengertian diskresi di atas maka dapat dikatakan bahwa secara sederhana diskresi adalah suatu wewenang menyangkut pengambilan suatu keputusan pada kondisi tertentu atas dasar pertimbangan dan keyakinan pribadi seseorang, dalam hal ini polisi. Brigadir Riky R. Siahaan mengatakan:

"bahwa dilakukan penahan bukan karena ada unsur pembalasan dari Kepolisian kepada pelaku, karena disini bukan hanya berbicara keselamatan korban saja tetapi juga keselamatan pelaku, karena keselamatan pelaku juga harus tetap di lindungi oleh pihak Kepolisian dan di Undang-Undang Sistem Peradilan Pidana Anak pun disitu menjelaskan bukan hanya kepentingan korban, tetapi juga kepentingan pelaku". 15

Tugas polisi sebagai penyidik dalam sistem peradilan pidana anak menempatkannya dalama jajaran paling depan, sehingga polisi dituntut untuk bisa menyeleksi atau memilah-milah perkara mana yang pantas untuk dilakukan diskresi.

Bahwa tugas pokok Kepolisian Negara Republik Indonesia diatur dalam Pasal 13 Undang-Undang Nomor 2 Tahun 2002 tentang Kepolisian Negara Republik Indonesia. Tugas pokok polri dalam pasal 13 diklarifikasikan menjadi 3 (tiga), yakni: memelihara keamanan dan ketertiban masyarakat; menegakkan hukum; dan memberikan perlindungan, pengayoman, dan pelayanan kepada masyarakat. Ketika menjalankan tugas pokok tersebut, ada 2 (dua) upaya yang digunakan aparat polri, yakni preventif dan represif.

1. Upaya preventif

Adalah usaha mencegah bertemunya niat dan kesempatan berbuat jahat, sehingga tidak terjadi kejahatan atau kriminalitas. Lingkup tugas upaya ini adalah seperti yang diuraikan dalam pasal 13 yang tersebut di atas kecuali menegakkan hukum. Tugas di bidang preventif dilaksanakan dengan konsep dan pola pembinaan dalam wujud pemberian peengayoman, perlindungan, dan pelayanan kepada

13 Brigadir Riky R. Siahaan, Selaku Kanit Unit Perlindungan Perempuan dan Anak Polres Tanjung Jabung Timur, Wawancara tanggal 15 Oktober 2019.

14 Aipda Juniar Simanjuntak, Selaku Kanit Unit Perlindungan Perempuan dan Anak Tahun 2011-2019 Polres Tanjung Jabung Timur, Wawancara tanggal 15 Oktober 2019.

15 Brigadir Riky R. Siahaan, Selaku Kanit Unit Perlindungan Perempuan dan Anak Polres Tanjung Jabung Timur, Wawancara tanggal 15 Oktober 2019. 
masyarakat, agar masyarakat merasa aman, tertib dan tentram, tidak terganggu segala aktivitasnya. Tindakan preventif ini biasanya dilakukan melalui cara penyuluhan, pengaturan, penjagaan, pengawalan, patrol polisi dan lain-lain sebagai teknis dasar kepolisian.

2. Upaya represif

Adalah tugas kepolisian dalam bidang peradilan atau penegakkan hukum, yang di bebankan kepada petugas, sebagaimana dikatakan bahwa petugas kepolisian dibebani dengan tanggung jawab khusus untuk memelihara ketertiban masayarakat dan menangani tindakan-tindakan kejahatan, baik dalam bentuk upaya pencegahan kejahatan agar supaya para anggota masyarakat dapat hidup dan bekerja dalam keadaan aman dan tentram.

Kewenangan penyidik yang tertuang pada pasal 16 ayat (1) Undang-Undang Nomor 2 Tahun 2002 tentang Kepolisian Negara Republik Indonesia khususnya pada huruf (a) melakukan penangkapan dan penahanan, penggeledaan dan penyitaan (h) mengadakan penghentian penyidikan, terkadang atau bahkan sering dalam praktiknya mengharuskan penyidik untuk melakukan diskresi.

Dengan demikiannya kekuasaan diskresi oleh polisi maka polisi memiliki kekuasaan yang besar karena polisi dapat mengambil keputusan dimana keputusannya bisa diluar ketentuan perundang-undangan, akan tetapi dibenarkan atau diperbolehkan oleh hukum. Sekalipun polisi dalam melakukan diskresi terkesan melawan hukum, namun hal itu merupakan jalan keluar yang memang diberikan oleh hukum kepada polisi guna memberikan efesiensi dan efektivitas demi kepentingan umum yang lebih besar.

\section{Kendala Apa Saja Yang Dihadapi Polres Tanjung Jabung Timur Dalam Menangani Kasus Anak Sebagai Pelaku Tindak Pidana}

Pada hakekatnya dalam menangani kasus anak sebagai pelaku tindak pidana merupakan suatu proses penyesuaian antara nilai-nilai dan pola perilaku nyata, yang bertujuan untuk mencapai kedamaian, sehingga tugas utama penegak hukum adalah mencapai keadilan.

Dalam proses menangani kasus anak, ada beberapa kendala yang dihadapi pihak Polres Tanjung Jabung Timur, terutama satuan Unit Perlindungan Perempuan dan Anak (UPPA) baik itu kendala internal maupun eksternal. Berdasarkan hasil dari wawancara penulis dengan AKP Gokma Uliate Sitompul selaku Kasat Reskrim Polres Tanjung Jabung Timur bahwa dalam menangani kasus anak terdapat beberapa kendala yang dihadapi, antara lain:

1. Kendala internal

Bahwa dari hasil wawancara ada beberapa kendala internal yang dihadapi pihak Kepolisian Tanjung Jabung Timur, diantaranya yaitu:

a. Pemahaman yang berbeda dalam penanganan kasus anak berhadapan dengan hukum dan korban di antara aparat penegak hukum, dilihat dari bagaimana penyidik melakukan penahanan untuk menghindari pembalasan

b. Penyidik sebagai aparat penegak hukum dalam melaksanakan tugasnya haruslah mempunyai pengetahuan yang luas tentang hukum. Pengetahuan para penyidik selaku aparat Kepolisian yang berada di lingkungan Unit Perlindungan Perempuan dan Anak sangat berbeda-beda. Hal tersebut 
dirasa sangat mempengaruhi tentang suatu tindakan yang dilakukan oleh penyidik dalam menangani suatu perkara pidana khususnya anak.

c. Kurangnya kerja sama antara pihak yang terlibat (aparat penegak hukum dan pekerja sosial anak), dikarenakan BAPAS dan pembimbing kemasyarakatan berada di kabupaten Tanjung Jabung Barat.

d. Terbatasnya sarana dan prasarana penanganan anak berhadapan dengan hukum selama proses peradilan (pra dan pasca putusan pengadilan). Apabila LPKS/LPAS tidak ada, maka seharusnya ada ruang pelayanan khusus di Kepolisian Negara Republik Indonesia khususnya di Polres Tanjung Jabung Timur.

e. Kurangnya partisipasi para pihak salah satu penghambat pelaksanaan penahanan oleh penyidik ialah partisipasi para pihak yang kurang dan pemahaman para pihak mengenai penyelesaian yang akan dilakukan penyidik terkadang tidak di respon dengan baik oleh pihak yang merasa dirugikan.

2. Kendala eksternal

Dalam melakukan diskresi masih banyak hambatan eksternal yang ditimbulkan yaitu:

a. Dasar Hukum yang belum kuat;

Dalam kaitannya dengan kewenangan pemberian diskresi ini faktor hukum dapat menjadi penghambat dalam penerapan diskresi oleh aparat hal tersebut disebabkan karena masih kurangnya aturan yang menjelaskan mengenai penggunaan kewenangan diskresi tersebut, pemahaman yang berbeda-beda di setiap aparat dalam menggunakan kewenangan diskresi, hal tersebut menjadikan hambatan penyidik dalam menerapkan kewenangan diskresi tersebut.

b. Adanya ganti rugi berupa materi atas kerugian dari akibat perbuaatan

Ganti rugi berupa materi yang tidak terlepaskan dalam perjanjian damai yang tidak menutup kemungkinan dapat menimbulkan masalah baru apabila dikemungkinan hari tidak dilaksanakan yang mana belum ada aturan yang bersifat mengikat dari pihak yang bertanggungjawab atas ganti rugi tersebut. Dalam konteks peradilan pidana anak, "ganti rugi yang diberikan pihak pelaku kepada pihak korban sangat mempengaruhi keberhasilan proses diversi. Dengan adanya ganti rugi tersebut pihak korban akan merasa bahwa pelaku bertanggungjawab atas perbuatannya serta pihak korban tidak akan merasa terbebani atas kerugian yang pernah dialaminya karena tindak pidana yang dilakukan oleh pelaku."

c. Kurangnya dukungan dan kerja sama antar lembaga

Masalah ini merupakan hambatan yang lain yang masih banyak terjadi dalam penegakkan suatu ketentuan hukum, termasuk penanganan anak berhadapan dengan hukum banyak kalangan professional hukum yang masih menganggap mediasi sebagai metode pencarian keadilan kelas dua yang mereka tidak berhasil mencapai keadilan sama sekali, padahal saat ini hakim adalah satusatu pihak yang bisa memediasi perkara anak yang berhadapan dengan hukum tidak seperti mediasi perdata yang memperbolehkan non-hakim menjadi mediator di pengadilan. Adanya pemahaman berdeda/stigma negatif terhadap 
anak sebagai pelaku tindak pidana yang tidak ditahan dalam proses penegakan hukum.

\section{SIMPULAN}

Berdasarkan hasil dari wawancara di atas, bahwa faktor yang menyebabkan dilakukannya penahanan semata-mata melindungi anak dari serangan balasan dari korban. Bahwa penahanan terhadap anak sangat jauh berbeda dengan penahanan orang dewasa, bahwa proses peradilan pidana anak baik dari tahap penyidikan sampai dengan tahap pembimbingan tidak diatur di dalam Undang-Undang Nomor 08 Tahun 1981 Tentang Kitab Undang-Undang Hukum Acara Pidana, melainkan di UndangUndang Nomor 11 Tahun 2012 Tentang sistem Peradilan Pidana Anak. Dari pengertian diskresi di atas penulis menyimpulkan bahwa Diskresi adalah suatu wewenang khusus yang diberikan kepada pihak kepolisian untuk mengambil suatu keputusan berdasarkan keyakinan, disini penulis menyimpulkan bahwa diskresi belum ada dasar hukum yang kuat, walaupun sebenarnya diskresi tersebut di atur dalam pasal 16 Undang-Undang Nomor 02 Tahun 2002 Tentang Kepolisan Negara Republik Indonesia, tetapi di pasal tersebut belum seluruhnya menjelaskan arti tentang diskresi tersebut.

Dalam menangani kasus anak, ada beberapa kendala yang dihadapi oleh pihak kepolisian. Dari hasil wawancara di atas ada 2 (dua) faktor yaitu; kendala internal dan kendala eksternal

1. Kendala internal

Bahwa kendala internal yang dihadapi pihak Kepolisian Polres Tanjung Jabung Timur adalah pemahaman yang berbeda-beda, baik antara aparat penegak hukum maupun keluarga kedua belah pihak korban dan pelaku, kurangnya kerja sama antara pihak yang terlibat (aparat penegak hukum dan pekerja sosial anak) dikarenakan BAPAS dan Pembimbing Kemasyarakatan berada di Kabupaten Tanjung Jabung Barat, terbatasnya sarana dan prasarana di Kabupaten Tanjung Jabung Timur sehingga tempat penahanan anak dilakukan di suatu ruangan khusus di Polres Tanjung Jabung Timur, padahal di pasal 33 ayat (4) dan (5) UndangUndang Nomor 11 Tahun 2012 mengatakan bahwa; penahanan terhadap anak dilaksanakan di LPAS (Lembaga Penempatan Anak Sementara), jika tidak terdapat LPAS di wilayah setempat penahanan dilakukan di LPKS (Lembaga Penyelenggaraan Kesejahteraan Sosial).

2. Kendala eksternal

Adanya ganti rugi berupa materi atas kerugian dari akibat perbuatan. Ganti rugi berupa materi yang tidak terlepaskan dalam perjanjian damai, yang tidak dapat menutup kemungkinan dapat menimbulkan masalah yang baru jika tidak dilaksanakan. Kurangnya dukungan dan kerja sama antara lembaga, sehingga hal ini adalah merupakan suatu kendala yang masih banyak terjadi dalam menangani kasus anak. 


\section{DAFTAR PUSTAKA}

\section{Dokumen Hukum}

Republik Indonesia, Undang-Undang Tentang Kepolisian Negara Republik Indonesia. UU Nomor 2 Tahun 2002.

Republik Indonesia, Undang-Undang Tentang Sistem Peradilan Pidana Anak. UU Nomor 11 Tahun 2012.

\section{Buku}

Djamil, M. Nasir. Anak Bukan Untuk Dihukum, Cet. 3, Sinar Grafika, Jakarta, 2015.

Gultom, Maidin. Perlindungan Hukum Terhadap Anak, Cet. 4, Edisi. Revisi, Refika Aditama, Bandung, 2014.

Koentjoro, Metodologi Penelitian Kualitatif, Jakarta: Salemba Humanika, 2011.

Nasution, Bahder Johan. Negara Hukum dan Hak Asasi Manusia, Cet. 3, Mandar Maju, Bandung, 2014.

Prakoso Abintoro, Hukum Perlindungan Anak, Laksbang Pressindo, Yogyakarta, 2016.

Pramukti, Angger Sigit dan Fuady Primaharsya, Sistem Peradilan Pidana Anak, Pustaka Yustisia, Yogyakarta, 2015.

Prasetyo, Teguh. Hukum Pidana, PT. Rajagrafindo Persada, Cet. 5, Jakarta 2015.

Saraswati, Rika. Hukum Perlindungan Anak di Indonesia, Cet. 2, PT Citra Aditya Bakti, Bandung, 2015.

Satori, Djam'an dan Aan Komariah Metode Penelitian Kualitatif, Alfabeta, Bandung, 2014.

Soetodjo, Wagiati. Hukum Pidana Anak, cet. 1, Refika Aditama, Bandung, 2006.

\section{Jurnal:}

Hafrida, Perlindungan Hukum Terhadap Anak Pelaku Tindak Pidana Pada Proses Penyidikan, Jurnal Ilmu Hukum, Volume 5, Nomor 6, Januari 2012. https://scholar.google.com/citations?user=xT8MpbIAAAAJ\&hl=en

Nurhaliza, Rina, Herry Liyus, Dheny Wahyudhi, Pelaksanaan Kesepakatan Diversi Pada Tingkat Penyidikan Dalam Sistem Peradilan Anak https://onlinejournal.unja.ac.id/Pampas/article/view/8097

Rahayu, Sri, Diversi Sebagai Alternatif Penyelesaian Perkara Tindak Pidana Yang Dilakukan Anak Dalam Perspektif Sistem Peradilan Pidana Anak, Jurnal Ilmu Hukum, 2007. https://www.neliti.com/id/publications/43317/diversisebagai-alternatif-penyelesaian-perkara-tindak-pidana-yang-dilakukan-ana

Sudarti, Elly, Perlindungan Hak Anak Dalam Penyidikan, Jurnal Ilmu Hukum, Volume 15, Nomor 1, April 2007. https://www.neliti.com/id/journals/jurnal-ilmuhukum-jambi 
Wahyudhi, Dheny, Perlindungan Terhadap Anak Yang Berhadapan Dengan Hukum Melalui Pendekatan Restorative Justice, Jurnal Ilmu Hukum, 2015. https://www.neliti.com/id/publications/43318/perlindungan-terhadap anak-yang-berhadapan-dengan-hukum-melalui-pendekatan-resto

Yudaningsih, Lilik Purwastuti dan Sri Rahayu. Reformasi Perlindungan Hukum Terhadap Anak Sebagai Pelaku Tindak Pidana Dalam Peradilan Pidana di Indonesia, Jurnal Ilmu Hukum.

https://www.neliti.com/id/publications/43220/reformasi-perlindunganhukum-terhadap-anak-sebagai-pelaku-tindak-pidana-dalam-pe 